\title{
GROUNDWATER RESOURCES ASSESSMENT OF GRANULAR AQUIFERS IN GREECE.
}

\author{
Kallioras A. ${ }^{1}$, Pliakas . $^{2}$ and Marinos P. ${ }^{3}$ \\ ${ }^{1}$ National Technical University of Athens, School of Mining \& Metallurgical Engineering, 15780, \\ Athens, Greece, kallioras@metal.ntua.gr \\ ${ }^{2}$ Democritus University of Thrace, Department of Civil Engineering, 67100, Xanthi, Greece \\ ${ }^{3}$ National Technical University of Athens, School of Civil Engineering, 15780, Athens, Greece
}

\begin{abstract}
Sound groundwater resources management is a matter of paramount importance in Circum-Mediterranean, for the ecologic status of the underlying aquifer systems. Freshwater resources in Greece are identified within all types of aquifer formations, however two distinct types are the ones that draw the attention of the scientific and the engineering community; the granular as well as the karst aquifers. This paper describes the groundwater resources potential that are found within granular aquifer formations, in combination with the major environmental threats associated with their exploitation and management.
\end{abstract}

Keywords: granular aquifers, karst aquifers, groundwater management, Greece.

\section{Пєрі́ $\eta \psi \eta$}

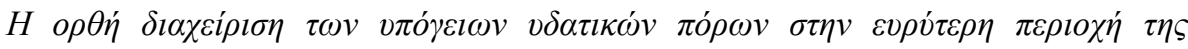

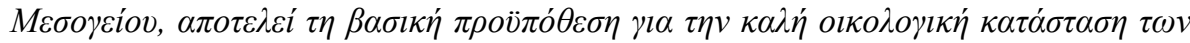

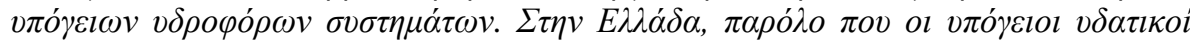

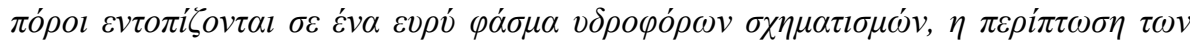

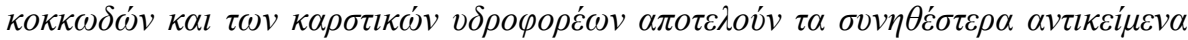

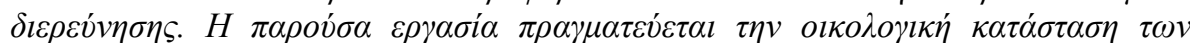

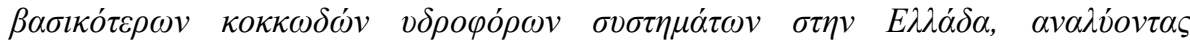

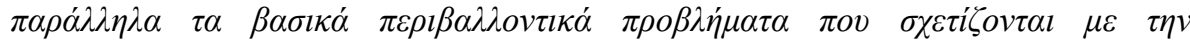

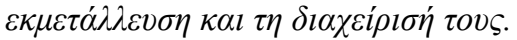

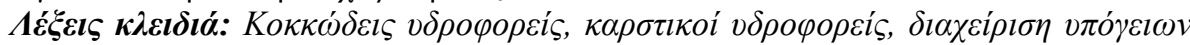

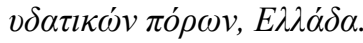

\section{Introduction}

Sound groundwater resources management is a matter of paramount importance in CircumMediterranean, for the ecologic status of the underlying aquifer systems. Freshwater resources in Greece are identified within all types of aquifer formations, however two distinct types are the ones that draw the attention of the scientific and the engineering community; the granular as well as the karst aquifers. This paper describes the groundwater resources potential that are found within granular aquifer formations, in combination with the major environmental threats associated with their exploitation and management. 


\section{Aquifer systems in Greece and GW management}

Daskalaki and Voudouris (2008), in their review for the groundwater quality of porous aquifers in Greece, identify the following geological formations: (a) Neogene (silt, marl, sandstone, and conglomerates) and Quaternary deposits; that cover about 30\% of Greece; (b) Carbonate formations, that cover $35 \%$ of the total area, mainly in central, western and southern parts of Greece; and (c) Impermeable formations (flysch, metamorphic and volcanic rocks, ophiolite, etc.).

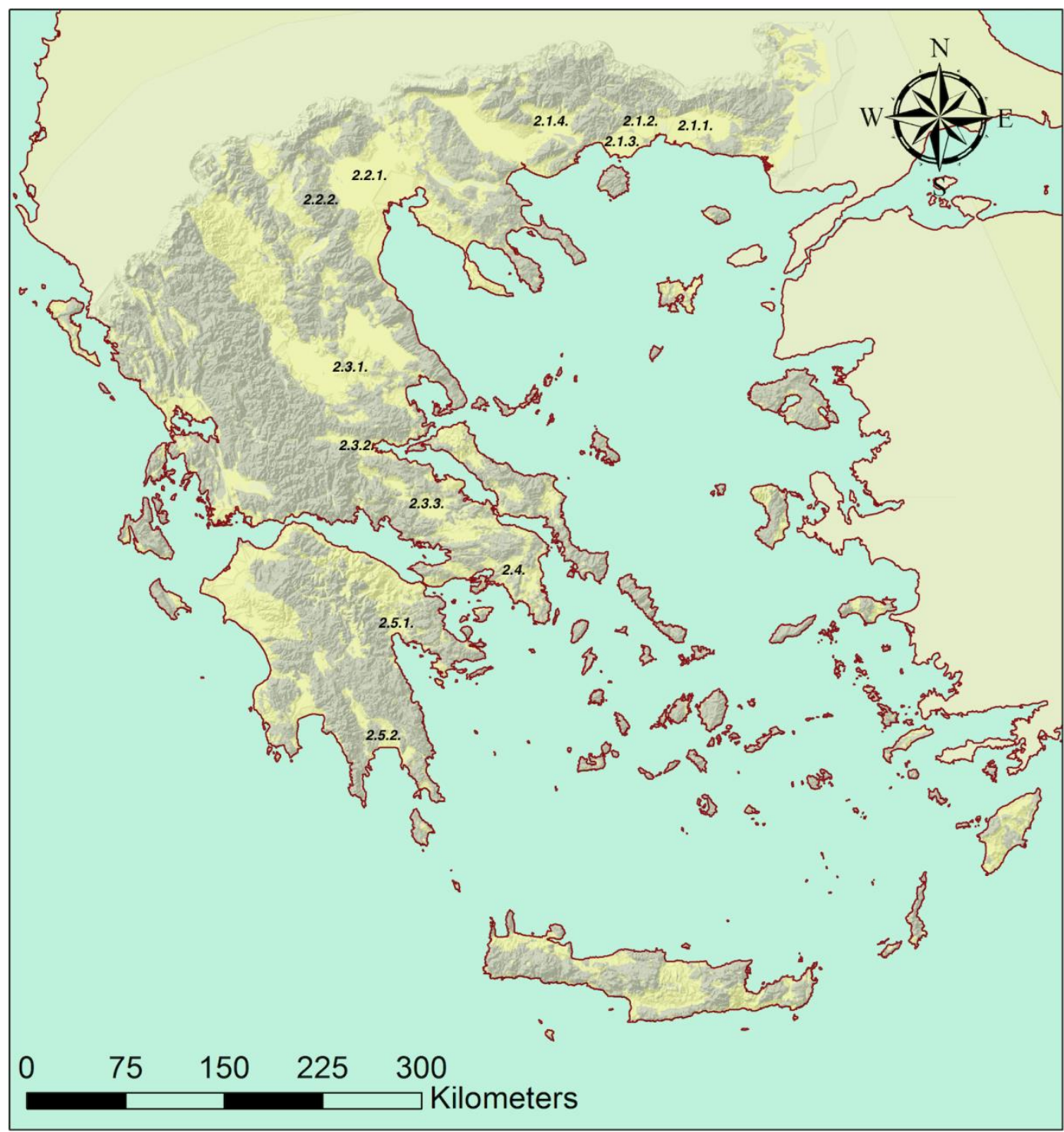

Figure 1 - Extent of granular aquifers in Greece (annotation is based on manuscript sections).

The same authors (Daskalaki and Voudouris, 2008) analyse that water needs are mainly met by groundwater abstracted from the aquifers via numerous wells and boreholes $(\sim 300,000$ for the whole of Greece). 


\subsection{Granular aquifer systems of NE Greece}

\subsubsection{Granular aquifers of Rhodope}

The most important aquifers of Rhodope are the unconsolidated hydrogeological systems of (i) River Kompsatos alluvial cone, (ii) the coastal aquifer system of Porpi, and (iii) the aquifer of $\mathrm{N}$. Sidirochori.

The Kompsatos alluvial aquifer has an area of app. $140 \mathrm{~km}^{2}$, has a combined thickness of 80 to more than $150 \mathrm{~m}$, while a sequence of alternations of fine-grained sediments of low permeability and coarse grained sedimentary deposits of various permeability constitutes the base of it (Petalas, 2013) and the hydraulic conductivity ranges from 0.4 to $2,870 \mathrm{~m} /$ day, averaging about $841 \mathrm{~m} /$ day.

The main geological formations of Porpi aquifer system are: (1) mudstones, sandstones, conglomerates and clays (which compose the upper geological formation responsible for the confined conditions of the aquifer system); (2) coarse-grained alluvial deposits (which compose the main aquifer layer); and finally, (3) the basement of the entire hydrogeological system which is composed of a grey-green clay layer (Kallioras et al., 2006a; Kallioras et al., 2006b; Kallioras, 2008; Recinos et al., 2015). The aquifer system suffers from seawater intrusion due to overpumping, while groundwater flow modeling applications (Kallioras et al., 2010) have shown that the system is under a negative hydrologic balance. Recent studies of Pisinaras et al. (2010), have also shown that due to irrigation practices with groundwater of degraded quality, the area of Porpi appears to face problems of soils salinization as well.

The aquifer system of N. Sidirohori, consists of a top silt layer (2-4 $\mathrm{m}$ thick) followed by alternating layers of fine and coarse sand and gravels (50-100 m thick), lying on a relatively thick layer of silt and greenish gray clay of the upper Miocene age, namely, the bedrock of the system (Pisinaras, et al., 2007a). This aquifer system suffers also from seawater intrusion, mainly caused by overpumping for irrigation purposes.

\subsubsection{Granular aquifer system of R. Kosynthos}

The unconsolidated aquifer system of R. Kosynthos involves three main geological formations (Pliakas, 1998): (i) the upper formation, 8-80 $\mathrm{m}$ in thickness, of low permeability, consisting of clayey sand which interchanges at certain locations with gravel sand of small thickness, (ii) the intermediate aquifer formation, $10-70 \mathrm{~m}$ in thickness, consisting of permeable gravel sand, considered as a shallow confined aquifer, in some locations changing to semi-confined aquifer, (iii) the lower impermeable formation consisting of clayey silt in depth of 30-90 m. In the past, a series of artificial recharge application took place (Pliakas et al., 2005) as a countermeasure to overexploitation conditions for irrigation purposes, while the groundwater flow models were developed to investigate future scenarios for the optimization of the aquifer system in question (Pliakas et al., 2005; Pisinaras et al., 2013).

\subsubsection{Granular aquifer system of R. Nestos delta}

The eastern delta of R. Nestos includes a coastal multi-aquifer system composed of a phreatic and a semi-confined aquifer layer underneath, both being recharged by the river and both being in hydraulic connection to the sea (Gkiougkis et al., 2015), extending to $176.4 \mathrm{~km}^{2}$, from which the $106 \mathrm{~km}^{2}$ are cultivated (only 60\%), while the coastal saline uncultivated lands extend to $45 \mathrm{~km}^{2}$. Recent vulnerability assessment studies (Pedreira et al., 2015) have shown that this coastal aquifer experiences low to moderate groundwater vulnerability to agrochemical contaminants, as well as moderate to high vulnerability to seawater intrusion.

\subsubsection{Granular aquifer of Drama}

The Drama basin is a tectonic graben located in the western part of Rhodope Massif (Panilas and Kallergis, 1997; Panilas, 1998). This sedimentary sequence -where metamorphic and igneous rocks constitute its basement and geologic/hydrogeologic boundaries- consists mainly of the following 
formations from older to younger (Panilas et al., 2008): (i) Fluvial and lacustrine sediments deposited during the Miocene and Pliocene, (ii) Terrestrial and fluvial sedimentation deposited Upper Pliocene to Middle Pleistocene, (iii) Lacustrine and telmatic sedimentation became dominant in the central part of the basin after the Middle Pleistocene, (iv) Holocene age deposits cover the rest of the plain, consisting of terrestrial alluvial sediments such as conglomerates, loams, talus cone deposits and peat accumulation in the Philippi sub-basin. This system has a negative groundwater hydrologic balance due to the overexploitation of the aquifers resources.

\subsection{Granular aquifer systems of N. Greece}

\subsubsection{Granular aquifer system of Thessaloniki region}

Thessaloniki plain which is located within the basin of Loudias is expanded to the west until the lower part of Aliakmonas River, to the east until Axios River and to the north until the city of Edessa. The basin of Mygdonia is also a very productive aquifer system that suffers from overexploitation during the last decades. Since this aquifer is hydraulically connected to Lake Koronia, the decline in groundwater levels of the aquifer led to a dramatic decline in the water capacity of the lake. Manakou et al. (2013) report that over the last four decades Lake Koronia, part of the Mygdonia Basin, operates under a negative water balance due to poor resource management and planning decisions, experiencing a pronounced ecosystem degradation over the past 30 years associated with water level reduction and nutrient loading from agricultural and industrial activities. The eastern and western basins of Axios River show also quite high groundwater resources potential that is exploitated mainly for agricultural purposes. Recent reports (Min Dev, 2003), mention that the estimated groundwater resources of all the above granular systems of Thessaloniki count up to $1,260 \mathrm{hm}^{3}$.

\subsubsection{Granular aquifer system of Western Macedonia Region}

The groundwater resources of the granular unconsolidated aquifer systems of western Macedonia Region, show much lower groundwater potential than the karstified aquifer systems; since the total estimated groundwater reserves within these formations is less than $280 \mathrm{hm}^{3}$. More specifically (Min Dev 2003) the units of Katerini; Upper part of Aliakmonas River-Ptolemaida-Florina; Almopia; and Lower part of Aliakmonas River have $115 \mathrm{hm}^{3}, 70 \mathrm{hm}^{3}, 63 \mathrm{hm}^{3}$ and $30 \mathrm{hm}^{3}$.

\subsection{Granular aquifer systems of Central Greece}

\subsubsection{Granular aquifer system of Thessaly}

Kallergis (1970) presents the granular aquifers by reporting: (i) Western Thessaly that includes the alluvial aquifer systems of Pinios-Portaikos-Pamisos and Sofaditis; and (ii) Eastern Thessaly that includes the alluvial aquifers of Tyrnavos and Karla.

According to recent reports (Min Dev 2008), the total groundwater abstraction that took place during the period 1974-1994 is estimated at $1000 \mathrm{hm}^{3}$, while $800 \mathrm{hm}^{3}$ mainly involve the period 1984-1994, fact which led to a water table depletion that has reached even $100 \mathrm{~m}$.

\subsubsection{Granular aquifer system of Sperchios valley}

Lithologically, Sperchios basin can be divided in three units: a) W boundaries, where flysch and clastic formations of Pindos unity are present, b) E boundaries, where limestone, ophiolites and schist-crest formations of Parnassos - Giona zone are present, c) S-SE boundaries, where the limestones of Parnassos - Giona zone is the dominating formation (Psomiadis E., 2010).The central part of Sperchios basin is covered by Quaternary formations, which consist of river and land deposits, such as clays, sands, conglomerates, detrital cones, stream deposits and breccia, whose composition and spreading depend on the adjacent or subjacent older formations (IGME, 2010a). The granular aquifer (alluvial and neogene deposits) has a thickness that reaches $300 \mathrm{~m}$, while the limestones and ophiolites of the area form the basement of this aquifer layer. Apostolopoulos (1993) quotes that further east from Ipati, in the area of the thermal fields, it increases from 600 to over 2,500 m under 
the Maliakos gulf. Stathopoulos et al. (2013) provide description on the water quality and the ecological status of the aquifer system within the alluvial valley of Sperchios, where it is distinct that typical contamination accurs in the groundwaters of the area. More specifically, the coastal part of the granular aquifer suffers from seawater intrusion due to quantitative degradation of the groundwater potential in the upstream part of the coastal zone. Additionally, high concentrations of nitrate loads were measured in several wells, which can be attributed to either point contaminant sources (uncontrolled landfills and untreated wastewater disposal) or diffuse contaminant sources such as extensive use of fertilizers and agrochemicals. Stathopoulos et al. (2013) also report the presence of salt accumulation within the delta area of Sperchios, which might lead to soil intense salinization and probably desertification.

\subsubsection{Granular aquifer system of $B$. Cephissus valley}

The granular aquifer system which is formed within the alluvial valley of B. Cephissus is mainly represented by the plain of Kopaida, which is the lower hydrogeological sub-basin of the valley (detailed analyzed in §4). It is hydraulically connected with the median route of Viotikos Kifisos basin (from W) and with mountain Elikonas (from S), which are the main sources of groundwater recharge (Tziritis, 2008; Tziritis, 2010).

\subsection{Granular aquifer systems of Attica}

The region of Attica, which covers the metropolitan area of Athens and the suburbs, is mainly composed of two types of aquifer formations, granular and karstic. Koutsoyiannis et al. (2008) provide information on the general characteristics of the underlying aquifers, together with information on the geographical location of the groundwater discharge if these systems.

\subsubsection{Granular aquifer system of Kifisos (Attica)}

The alluvial aquifer of Kifisos (Attica) is highly urbanized, fact which greatly influences the recharge through infiltration. On the other hand, the aquifer is not significantly exploited, except from some minor abstraction locations for limited water uses. The quality of the groundwaters though is rather degraded, mainly due to point source pollution, with nitrate loas being the major contaminant (exceeding even 500mg/L according to Min Dev, 2003). At locations where there are industrial activities, the water shows high concentrations of heavy metals (mainly $\mathrm{Zn}$ ).

\subsubsection{Granular aquifer system of Mesogeia}

The aquifer system of Mesogeia is a rather interesting granular aquifer system that is highly influenced from the radical changes in land use during the last 15years. The area was mainly agricultural (vineyards and olive trees being the most dominant cultivation type), and only a small part of it was urbanized (app. 25-20\%). However, due to the expansion of the metropolitan area towards Mesogeia -in combination with the construction of the International Airport of Athens- the area is now almost $80 \%$ urbanized. This abrupt change has also effected the quality of the groundwaters of the area. Before the urbanization period, the major contaminants of the aquifer were point and diffuse source of nitrate loads (mainly of agricultural origin and disposal of untreated sewage) as well as chlorides from seawater intrusion. At present, the high levels of $\mathrm{Ni}, \mathrm{Cr}, \mathrm{Co}, \mathrm{Mn}$ and $\mathrm{Fe}$ in agricultural soils are associated with geological parent materials whereas $\mathrm{Pb}, \mathrm{Zn}$ and $\mathrm{Cu}$ mainly originated from anthropic activities (Kaitantzian et al., 2013). 


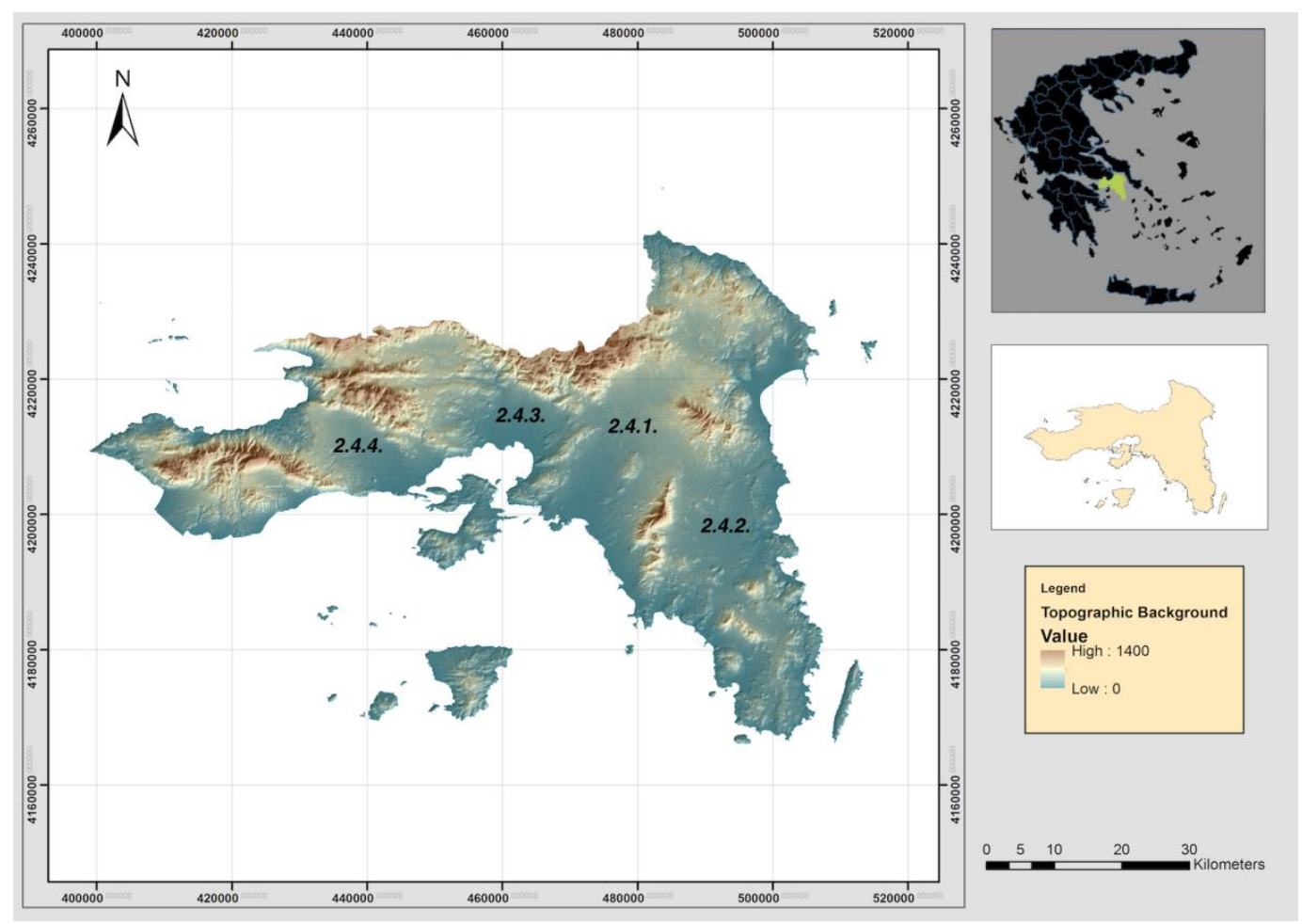

Figure 2 - Extent of granular aquifers in Attica.

\subsubsection{Granular aquifer system of Thriasio}

Thriasian plain aquifer is a typical coastal Mediterranean aquifer system of alluvial deposits, subject to overexploitation. Main aquifer contaminants are considered to be nitrates and chlorides mainly due to untreated wastewater disposal and/or agrochemical contamination for the former; and seawater intrusion for the latter.

\subsubsection{Granular aquifer system of Megara}

Megara is also a typical case study for a coastal alluvial aquifer system that suffers from both nitrate contamination (same pollution sources as in the case of Thriasian plain) and seawater intrusion (high concentrations of chlorides).

\subsection{South and Eastern Peloponesse}

\subsubsection{Granular aquifer system of Argos}

The plain of Argos, southern Greece, is perhaps the first region in Greece where the phenomenon of seawater intrusion in groundwater was noticeably observed by late fifties. This fact has motivated the collection and processing of numerous of pertinent data, which particularly concern the detailed monitoring of the evolution of the phenomenon. The saline front has already affected the southern and central part of the plain while another saline body has appeared along the northeastern part of the plain within the limestone aquifers of Monastiraki, Manesi and Midea villages (Giannoulopoulos, 2000).

\subsubsection{Granular aquifer system of Evrotas}

River Evrotas flows through the valley of Lakonia (length of river-course app. 82km), where the city of Sparta is located, and is bounded by Taygetos and Parnonas, whereas its catchment area is app. $1875 \mathrm{~km}^{2}$ (Angelidis et al., 1995). Within this part of Evrotas basin, a granular aquifer system 
is developed, which is mainly phreatic and semi-confined at certain parts (Karalemas, 2012), suffering from long term anthropogenic activities (Angelidis et al., 1996) that deteriorate its groundwater resources. Typical quality issues deal with both surface- and ground-water resources of the area, such as seawater intrusion, disposal of untreated wastewater and contamination from agrochemicals due to extensive agricultural activities.

\section{Conclusions}

Granular aquifer systems in Greece are subject to: (i) quantitative deterioration as a result of intense exploitation for agricultural activities as well as (ii) qualitative degradation mainly due to unmanaged use of agrochemicals, disposal of untreated (or not properly treated) wastewater and seawater intrusion.

It is now evidenced that all coastal granular aquifers suffer from seawater intrusion, while in many cases (e.g. aquifer systems of Thessaly) the depletion of the water table has reached $100 \mathrm{~m}$. Main groundwater uses for the above case is agriculture, however, cases are also related to mining activities.

Alluvial aquifers that are formed within major river basins (e.g. Pinios, Sperchios, B. Cephissus) mainly suffer from increased nitrate concentrations, due to intensive agricultural activities that occur within their boundaries.

\section{References}

Angelidis, M.O., Markantonatos, P.G. and Bacalis, N.Ch., 1995. Impact of human activities on the quality of river water: the case of Evrotas River catchment basin, Greece, Environmental Monitoring and Assessment, 35, 137-153.

Angelidis, M.O., Markantonatos, P.G., Bacalis, N.Ch. and Albanis, T.A., 1996. Seasonal fluctuations of nutrients and pesticides in the basin of Evrotas River, Greece, Journal of Environmental Science and Health, Part A: Environmental Science and Engineering and Toxicology, 31(2), 387-410.

Apostolopoulos, G., 1993. Geophysical studies in the Sperchios basin, Doctoral Thesis submitted to the Department of Geology, University of Athens (in Greek).

Giannoulopoulos, P., 2000. Groundwater hydraulics and mathematical modeling in Argos plain, Doctoral Dissertation, Agricultural University of Athens, Athens, Greece.

Daskalaki, P. and Voudouris, K., 2008. Groundwater quality of porous aquifers in Greece: a synoptic review, Environmental Geology, 54, 505-513.

Gkiougkis, I., Kallioras, A., Pliakas, F., Pechtelidis, A., Diamantis, V., Diamantis, I., Ziogas, A. and Dafnis, I., 2015. Assessment of soil salinization at the eastern Nestos River Delta, N.E. Greece, CATENA, In Press, doi: 10.1016/j.catena.2014.06.024.

Institute of Geological and Mineral Exploration, IGME, 2010a. Survey and assessment of hydrogeological characteristics of groundwaters and aquifer system in Greece, Report of the Section of Water Resources and Environment, Division of Hydrogeology-IGME, SubProject No.6, Water District 08, Ref.No. 7.3.2.1.9., by Dr. A. Manakos, 581 pp.

Institute of Geological and Mineral Exploration, IGME, 2010b. Survey and assessment of hydrogeological characteristics of groundwaters and aquifer system in Greece, Report of the Section of Water Resources and Environment, Division of Hydrogeology-IGME, SubProject No.9, Water District 07, Ref.No. 7.3.2.1.9., by Tsioumas V. and Zorapas V., 139 pp.

Kaitantzian, A., Kelepertzis, E. and Kelepertsis, A., 2013. Evaluation of the Sources of Contamination in the Suburban Area of Koropi-Markopoulo, Athens, Greece, Bulletin of Environmental Contamination and Toxicology, 91(1), 23-28.

Kallergis, G., 1970. Hydrogeological Investigation of Kalampaka Sub-Basin (W. Thessaly), Publications of the Greek, Institute of Geological and Mineralogical Exploration, XIV/1, 197 pp. 
Kallioras, A., 2008. Groundwater resources management of aquifers subjected to seawater intrusion regime. The case of western coastal plain of the Prefecture of Rhodope, Doctoral dissertation submitted to the Department of Civil Engineering, Democritus University of Thrace, Xanthi, Greece, 2008, 333 pp. (In Greek).

Kallioras, A., Pliakas, F. and Diamantis, I., 2006a. Conceptual model of a coastal aquifer system in northern Greece and assessment of saline vulnerability due to seawater intrusion conditions, Journal of Environmental Geology, 51(3), 349-361.

Kallioras, A., Pliakas, F. and Diamantis, I., 2010. Simulation of Groundwater Flow in a Sedimentary Aquifer System Subjected to Overexploitation, Water, Air and Soil Pollution, 211, 177-201.

Kallioras, A., Pliakas, F., Diamantis, I. and Emmanouil, M., 2006b. Application of Geographical Information Systems (GIS) for the management of coastal aquifers subjected to seawater intrusion, Journal of Environmental Science and Health, Part A: Toxic/Hazardous Substances and Environmental Engineering, Taylor \& Francis, Inc., Philadelphia, USA, A41(9), 2027-2044.

Karalemas, N., 2012. Qualitative and quantitative characteristics of Eastern Taigetos and Mani hydrosystems; Prospects for sustainable exploitation, Doctoral Dissertation, Faculty of Geology and Geoenvironment, National and Kapodistrian University of Athens, Athens, Greece.

Koutsoyiannis, D., Andreadakis, A., Mavrodimou, R., Christofides, A., Mamassis, N., Efstratiadis, A., Koukouvinos, A., Karavokiros, G., Kozanis, S., Mamais, D. and Noutsopoulos, K., 2008. National Programme for the Management and Protection of Water Resources, Support on the compilation of the national programme for water resources management and preservation, Department of Water Resources and Environmental Engineering - National Technical University of Athens, Athens, February 2008, 748 pp.

Manakou, V., Tsiakis, P. and Kungolos, A., 2013. A mathematical programming approach to restore the water balance of the hydrological basin of Lake Koronia, Desalination and Water Treatment, 51, 13-15.

Ministry of Development, MinDev, 2003. Master plan for water resource management of the country, Report prepared by the Department of Water Resources, Hydraulic and Maritime Engineering (National Technical University of Athens), Institute of Geological and Mining Research, and Centre for Research and Planning, for the Department of Water and Natural Resources of the Ministry of Development, Athens, January 2003, 549 pp.

Panilas, S. and Kallergis, G., 1997. Contribution to hydrogeological and hydrogeochemical condition in the groundwater of lignite field in Drama area, Greece (in Greek), Hellenic Hydrogeological Congress Thessaloniki, 1997, 393-407.

Panilas, S., 1998. Hydrogeological problems concerning the open pit exploitation of lignite deposits. The case of the Drama lignite deposit (in Greek), PhD Thesis, Department of Geology, University of Patras.

Pedreira, R., Kallioras, A., Pliakas, F., Gkiougkis, I. and Schuth, C., 2015. Groundwater vulnerability assessment of a coastal aquifer system at River Nestos eastern Delta, Greece, Environmental Earth Sciences, In Press, doi: 10.1007/s12665-014-3864-7.

Petalas, C., 2013. A preliminary assessment of hydrogeological features and selected anthropogenic impacts on an alluvial fan aquifer system in Greece, Environmental Earth Sciences, 70(1), 439-452.

Pisinaras, V., Petalas, C., Gemitzi, A. and Tsihrintzis, V.A., 2007a. Water quantity and quality monitoring of Kosynthos River, North-Eastern Greece, Global NEST Journal, 9(3), 259-268.

Pisinaras, V., Petalas, C., Tsihrintzis, V.A. and Karatzas, G.P., 2013. Integrated modeling as a decision-aiding tool for groundwater management in a Mediterranean agricultural watershed, Hydrol. Process, 27, 1973-1987.

Pisinaras, V., Tsihrintzis, V.A., Petalas, C. and Ouzounis, K., 2010. Soil salinization in the agricultural lands of Rhodope District, northeastern Greece, Environ Monit Assess, 2010, 166, 79-94.

Pliakas, F., Petalas, C., Diamantis, I. and Kallioras, A., 2005. Modeling of groundwater artificial recharge by reactivating an old stream bed, Water Resources Management, 19, 279-294. 
Pliakas, F., 1998. Research in the appropriate artificial recharge methods in alluvial aquifer systems. Doctoral Dissertation, Democritus University of Thrace, Department of Civil Engineering, Xanthi, Greece (in Greek).

Psomiadis, E., 2010. Research of the geomorphological and environmental changes in the hydrological basin of Sperchios River by using new techniques, Phd thesis, Agricultural University of Athens.

Recinos, N., Kallioras, A., Pliakas, F. and Schuth, C., 2015. Application of GALDIT index to assess the intrinsic vulnerability to seawater intrusion of coastal granular aquifers, Environmental Earth Sciences, 73(3), 1017-1032.

Stathopoulos, N., Rozos, D. and Vasileiou, E., 2013. Water resources management in Sperchios river basin, using SWOT analysis, Bulletin of the Geological Society of Greece, vol. XLVII, Proceedings of the 13 International Congress, Chania, Sept. 2013, 2, 779-788.

Tziritis, E., 2008. Hydrogeochemical - Environmental study of east Kopaida - Yliki karstic system and assessment of vulnerability with the use of Geoinformatics, $\mathrm{PhD}$ thesis, University of Athens, $512 \mathrm{pp}$.

Tziritis, E., 2010. Assessment of NO3 - contamination in a karstic aquifer, with the use of geochemical data and spatial analysis, Environmental Earth Sciences, 60(7), 1381-1390. 